Article

\title{
Design of an Optimized Thermal Management System for Li-Ion Batteries under Different Discharging Conditions
}

\author{
Ankur Bhattacharjee ${ }^{1}$, Rakesh K. Mohanty ${ }^{1}$ and Aritra Ghosh ${ }^{2,3, *(D)}$ \\ 1 Department of Electrical and Electronics Engineering, BITS-Pilani, Hyderabad Campus, \\ Telangana 500078, India; a.bhattacharjee@hyderabad.bits-pilani.ac.in (A.B.); \\ h20191400554@hyderabad.bits-pilani.ac.in (R.K.M.) \\ 2 Environment and Sustainability Institute, University of Exeter, Penryn Campus, Cornwall TR10 9FE, UK \\ 3 College of Engineering, Mathematics and Physical Sciences, Renewable Energy, University of Exeter, \\ Cornwall TR10 9FE, UK \\ * Correspondence: A.Ghosh@exeter.ac.uk
}

Received: 2 October 2020; Accepted: 27 October 2020; Published: 30 October 2020

\begin{abstract}
The design of an optimized thermal management system for Li-ion batteries has challenges because of their stringent operating temperature limit and thermal runaway, which may lead to an explosion. In this paper, an optimized cooling system is proposed for $\mathrm{kW}$ scale Li-ion battery stack. A comparative study of the existing cooling systems; air cooling and liquid cooling respectively, has been carried out on three cell stack $70 \mathrm{Ah} \mathrm{LiFePO}_{4}$ battery at a high discharging rate of $2 \mathrm{C}$. It has been found that the liquid cooling is more efficient than air cooling as the peak temperature of the battery stack gets reduced by $30.62 \%$ using air cooling whereas using the liquid cooling method it gets reduced by $38.40 \%$. The performance of the liquid cooling system can further be improved if the contact area between the coolant and battery stack is increased. Therefore, in this work, an immersion-based liquid cooling system has been designed to ensure the maximum heat dissipation. The battery stack having a peak temperature of $49.76{ }^{\circ} \mathrm{C}$ at $2 \mathrm{C}$ discharging rate is reduced by $44.87 \%$ to $27.43{ }^{\circ} \mathrm{C}$ after using the immersion-based cooling technique. The proposed thermal management scheme is generalized and thus can be very useful for scalable Li-ion battery storage applications also.
\end{abstract}

Keywords: Li-ion battery; thermal behavior; discharge rate; cooling techniques; liquid cooling

\section{Introduction}

In today's world of transportation technology, electric vehicles (EVs) have drawn an increasing demand because of the impending challenges the world is facing due to the heavy exploitation of existing fuels. The electric vehicles are powered primarily by batteries. Lithium-ion batteries claim to be one of the most suitable batteries for the EVs because of their high energy density, long cycle life, modular and low maintenance and eco-friendly features. The reliable operation of these batteries in EV applications requires an efficient battery management system [1]. So far in many research articles, it has been found that the surrounding temperature has a high impact on the battery life cycle and its state of health (SOH). In tropical climates, under contentious conditions, the battery lifetime can undergo degradation by $66 \%$ [2]. In cold climate countries, batteries working under frigid conditions result in a significant decrement of its state of health $(\mathrm{SOH})$ [3]. Also, under some abnormal charging and discharging conditions, if a battery undergoes thermal runaway then the heat released can cause a catastrophic thermal failure [4] leading to a hazardous explosion.

Therefore, it is evident that the battery operating temperature is one of the vital parameters that determine the life cycle of it. Li-ion batteries, have such stringent operating temperature band to 
ensure reliable performance in the field. Several research works have been done on how to improve the performance of Li-ion batteries even under high temperatures so that it has stable operation and reduces the chances of thermal runaway. The main approach is to devise the necessary components that can control the thermal instability of batteries, also called the battery thermal management system (BTMS). For Li-ion batteries a BTMS is an essentially required sub-system while being operated under high surrounding temperatures. The BTMS controls the battery temperature rise to stop the occurrence of a thermal runaway leading to safe operation and improved cycle life of the battery. Several cooling techniques [5] that have been proposed over the years such as air cooling, liquid cooling, phase change of material (PCM) etc. Zolot et al. [6-8] implemented the air cooling technique for NiMH battery packs of hybrid electric vehicles (HEVs) and estimated the thermal behavior of the battery. Choi and Kang [9] demonstrated a model controlling the temperature, evaluating the required capacity of cooling by investigating most of the cooling methods which are in practical use. They analyzed the variation of temperature of the battery with the application of these various cooling methods. Pesaran, Kim et al. $[10,11]$ evaluated the benefits and the deficiencies of both liquid and air cooling. Chacko et al. [12] assessed the merits of indirect cooling using liquid for batteries and derived that this method has a strong potential to achieve the thermal management system for a battery. Yeow et al. [13] considered finned cooling and found the use of air to be effective in the removal of heat from fins concerning liquid cooling. Wu et al. [14] introduced a design that used heat pipes to reduce the temperature rise.

Of all the above-mentioned cooling techniques, the simplest one is the direct air-cooling method [15]. Air cooling method is based on the fundamental concept of convection to dissipate heat from the battery cells into its enclosing environment. Often the forced air-cooling system is used in a controlled manner aiming cooled air into the battery cells. Under the lower rate of charging/discharging, the temperature rise is low and this will work efficiently. However, an increased rate of charging/discharging results in a sudden rise in temperature which requires a considerable amount of air to be directed towards the battery module to abate the enhanced temperature $[16,17]$.

The second most commonly used method for cooling is the liquid cooling method [18], generally implemented in two ways, direct cooling and indirect cooling method. The indirect cooling method is the most widely used method where a nonconductive liquid flows through vents which are in contact with the battery module and absorb the heat from it and release it to the outer environment through a heat exchanger or a radiator fan. Since it is an indirect method of cooling it works on the principle of conduction. The other forms of liquid cooling include the direct cooling method where the coolant is directly placed in contact with the battery. This method requires a coolant that should be nonconductive in nature and should have a low coefficient of expansion. Because of these stringent requirements, this method is still in the research stage. There are some other forms of cooling methods used in some EV models; one of them is the refrigerant based cooling [19] which is a sub-class of the liquid cooling system. The refrigerant coolant allows for flow precisely through the cell inside the attached cooling plate. The generated heat is then dissipated through the coolant during its change of phase. In this method, the loss occurred during the heat exchange is minimized in comparison to other methods and the process is more dynamic and administrable. Also, the coolant used here has a lower electrical conductivity which results in a reduced chance of short circuit. Despite more power consumption, results have shown it to be a promising method. Nevertheless, air cooling, indirect liquid cooling are the most implemented techniques in the EVs.

A subclass of the liquid cooling method called the immersion-based cooling system is used in applications where the heat dissipation is the maximum. The efficiency of the cooling technology should be the maximum as it should remove the maximum amount of heat within a short period of time. This method has been implemented for cooling of lithium ion batteries [20]. In this method, the battery is immersed directly inside a liquid coolant where the heat can be dissipated through the coolant directly. In spite of higher cooling efficiency, this method has not been implemented yet for the Lithium batteries used in electric vehicles (EVs) as the coolant to be used should not expand with the 
increase in temperature and should have less electrical conductivity. Some coolants are engineered with these properties and are in the research stage.

In this paper, a COMSOL Multiphysics based $\mathrm{LiFePO}_{4}$ battery stack has been modeled and the temperature rise inside the stack has been observed under different discharging rates. Considering the temperature at a fixed discharging rate, the air cooling and liquid cooling technique have been applied to the Li-ion battery. Simulation studies are performed under different flow rates of air and liquid and the variation of temperature under each case is analyzed. An optimized liquid immersion-based cooling system has also been proposed in this work and the performance of this method is compared with the conventional liquid cooling methods. To validate the simulated models a practical 4.2 Volts/cell, three cell 70Ah $\mathrm{LiFePO}_{4}$ battery specifications has been considered in this paper.

Rest of the paper contains the following sections. Section 2 comprises of thermal behavior study and analysis. Section 3 shows thermal management techniques. Different modeling aspects have been shown in Section 4. Section 5 describes the result and discussion. Section 6 introduces the proposed modified liquid cooling technique. Section 7 describes the performance of the proposed thermal management technique. Finally, Section 8 includes the conclusion of the paper.

\section{Thermal Behavior Study and Analysis}

The efficiency of a battery is decided by the operating temperature and the charging and discharging rate. The life cycle of a battery improves if it operates under the desired working temperature. However, if, the temperature exceeds it may trigger spontaneous reactions inside the cells which will result in thermal runaway. The main cause of rising in temperature of a battery is its charging and discharging rate. Under high charging/discharging rate an increased inflow and outflow of current occurs resulting in high power dissipation causing a temperature rise. The first modeling of a battery to determine the thermal behavior was done by Bernardi et al. [21]. The heat generated in a battery has been modeled as a function of both reversible and irreversible heat $[22,23]$

$$
\begin{gathered}
Q_{t o t}=Q_{i r r}+Q_{r e v} \\
Q_{i r r}=R_{i n t} I^{2} \\
Q_{r e v}=-I T\left(\partial E_{e q} / \partial T\right)
\end{gathered}
$$

where $Q_{t o t}$ is the rate of heat generated in the battery; $Q_{i r r}$ and $Q_{\text {rev }}$ are the irreversible heat generated and the reversible heat generated respectively; $R_{\text {int }}$ is the resistance of the battery; I current flowing; $E_{e q}$ is the electromotive force at a certain state of charge under equilibrium.

\subsection{Case Study for Temperature Rise under Different Discharge Rates}

To analyze the thermal behavior of a battery and the effect of the rate of charging/discharging a Li-ion battery cell of $70 \mathrm{Ah}$ having dimensions $127 \mathrm{~mm}$ width, $229 \mathrm{~mm}$ length, and $45 \mathrm{~mm}$ thick has been considered as shown Figure 1.

All the required modeling and simulations have been performed using COMSOL Multiphysics environment. Various modeling aspects of the Li-ion battery and the cooling methods have been performed under a high discharging rate and results are obtained.

Figure 2 shows the discharge curve for the battery at different $C$ rates at an ambient temperature of $25^{\circ} \mathrm{C}$. The battery cell is generally used for realizing the EV battery packs having an energy density of $130.5 \mathrm{Wh} / \mathrm{kg}$. Anode material of the battery is of graphite whereas $\mathrm{LiFePO}_{4}$ as the cathode material. In this paper, for estimation of the heat produced inside the battery pack comprising of three cells to form a rectangular (prismatic) shape stack. A T-type thermocouple has been integrated over the battery surface to observe the temperature. 


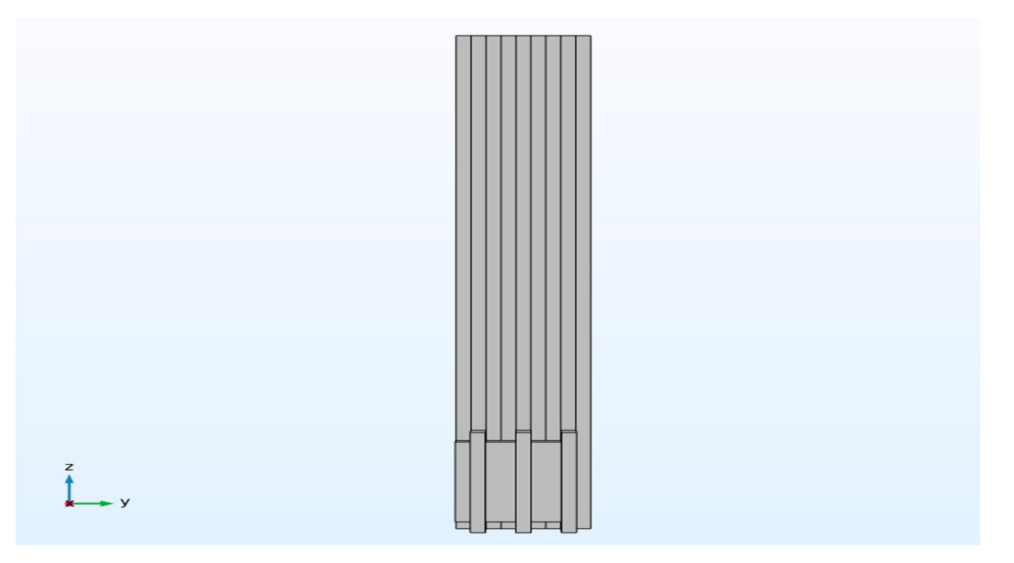

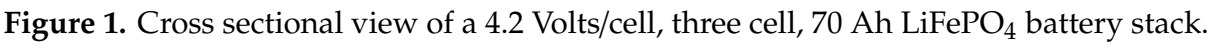

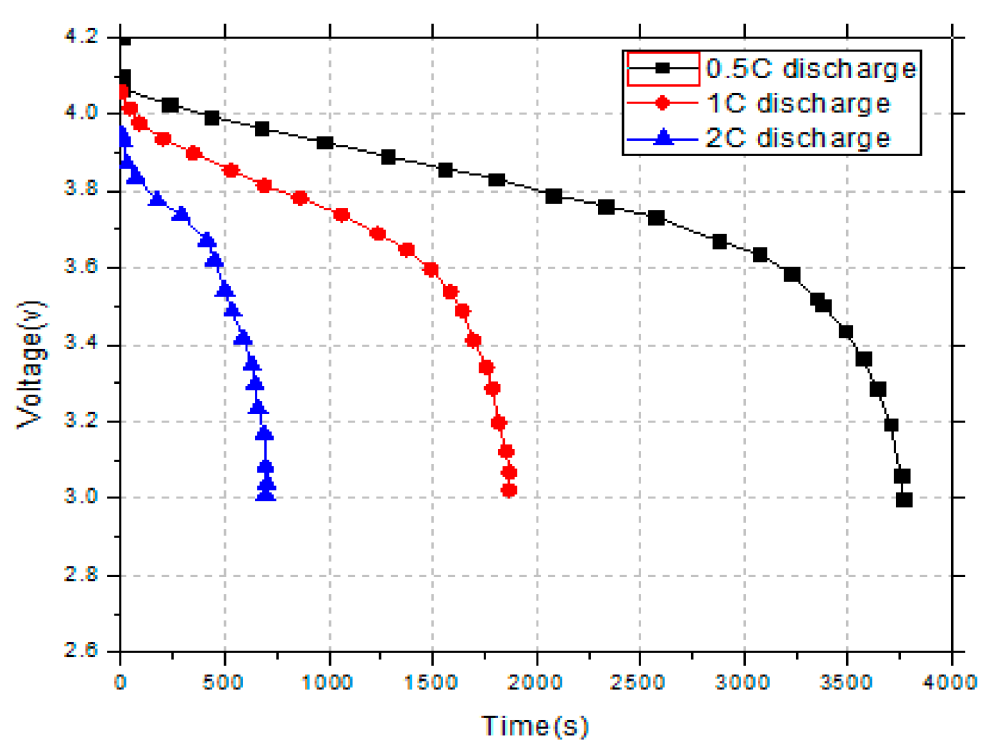

Figure 2. Discharge characteristics of $\mathrm{LiFePO}_{4}$ battery at different ' $C$ ' rates.

Figure $3 \mathrm{a}$ shows the battery voltage profile at $2 \mathrm{C}$ discharge rate. Figure $3 \mathrm{~b}$ shows the temperature rise in the battery stack under different discharging rates. Under $2 \mathrm{C}$ discharge rate, the battery temperature reaches to a maximum value of $49.76^{\circ} \mathrm{C}$ and this could lead to a thermal shutdown of the battery by the protection circuit. Similarly, under $1 \mathrm{C}$ discharge rate temperature rises to $44.87^{\circ} \mathrm{C}$ and under $0.5 \mathrm{C}$ maximum temperature value is found to be $34.58^{\circ} \mathrm{C}$. In this work, the battery thermal management has been done considering the battery voltage characteristic and the temperature rise under $2 \mathrm{C}$ discharge rate. At higher discharge rate the Li-ion battery temperature rapidly increases which can cause damage to battery health and hence it needs to be controlled. 


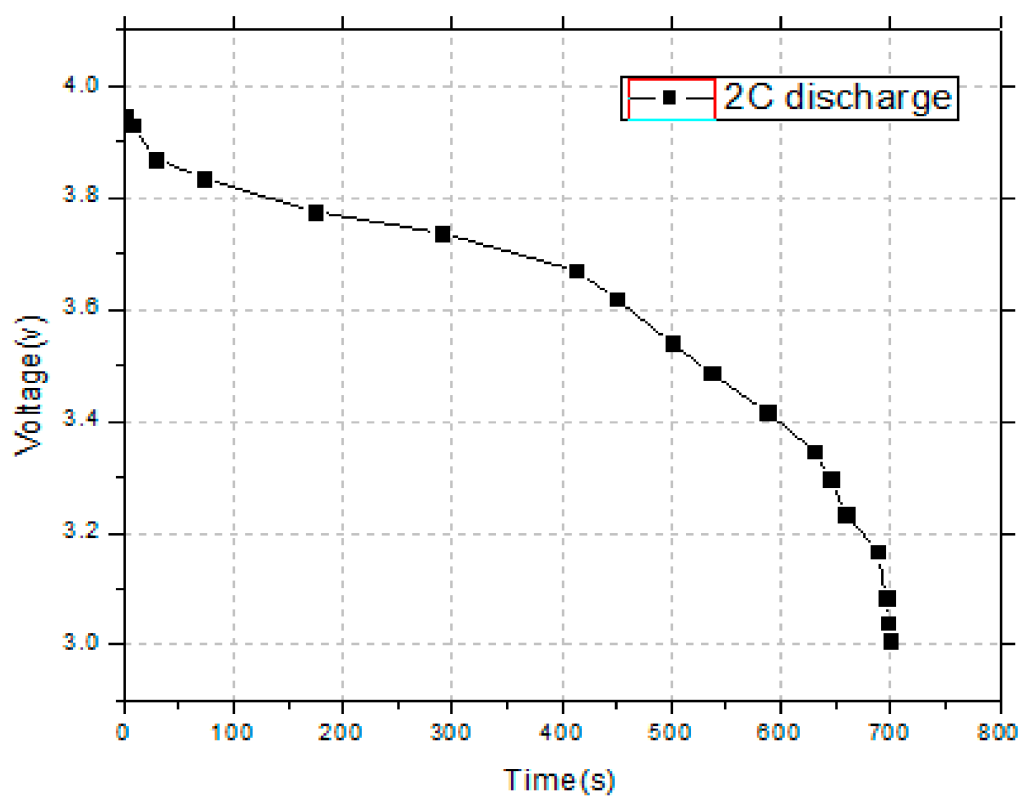

(a)

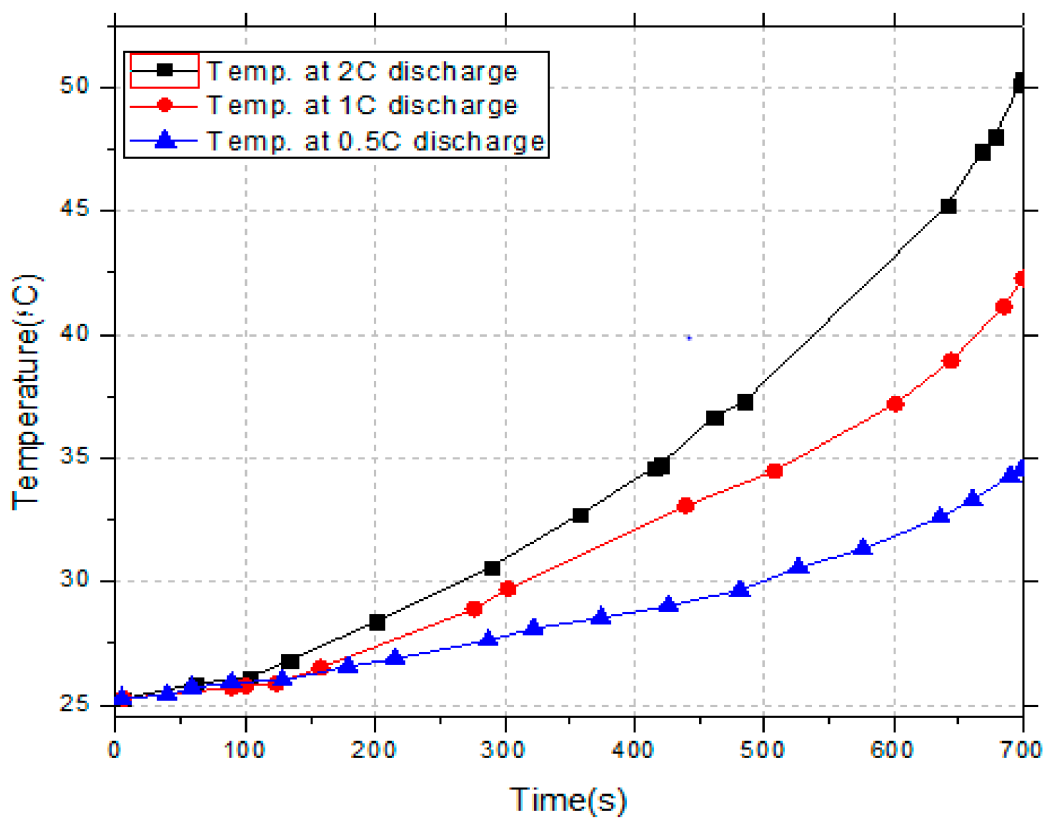

(b)

Figure 3. Temperature and voltage characteristics of the Li-ion battery: (a) Battery voltage during discharging at $2 \mathrm{C}$ rate; (b) Battery temperature rise during discharging at three different rates.

\subsection{Thermal Runaway}

The primary requirement of a thermal management system is to ensure the safe operation of a battery under dynamic working conditions. Different factors such as the cell composition [24,25], working conditions, initial conditions [26-29], overloading conditions etc., affect the safety of a battery. When Li-ion batteries are functioning under such extreme conditions it results in several internal chemical reactions and produces a high amount of heat in a short time causing thermal runaway [30]. This discharge of excessive amounts of heat and gases results in battery fire and explosion [31]. 
Generally, such conditions occur because of the detachment of cells from each other inside the battery pack [32], and in certain conditions, short-circuit occurs in a battery because of overcharging [33].

In Ref. [34] it has been analyzed that in cold climatic conditions because of excess low temperature the battery can freeze and a decline in its capacity whereas in hot and humid conditions the chemical components responsible for reactions get damaged. Hence, for safer use of the battery, the causes and effects of a thermal runaway have to be mitigated. To improve the thermal performance of a cell, different parts of the cell are applied with layers of various materials $[35,36]$. These techniques can be used at the cell level but a large number of cells in use will release an excessive amount of heat and diffusion of the heat through the cells can cause thermal runaway [37]. Therefore, to restrict the temperature rise inside the battery pack and dissipation of heat some thermal management systems are implemented $[31,38]$. Figure 4 shows the temperature distribution inside a $\mathrm{LiFePO}_{4}$ battery cell. The temperature appears to be the maximum at the core of the battery cell and confined within a small space leading to an internal short circuit. This phenomenon occurs because of high current densities forming when the two electrodes of the battery come in contact with each other. When the current density increases faster at a confined space the temperature also increases which can trigger spontaneous exothermic reactions thus causing a breakdown of the electrolyte leading to thermal runaway.

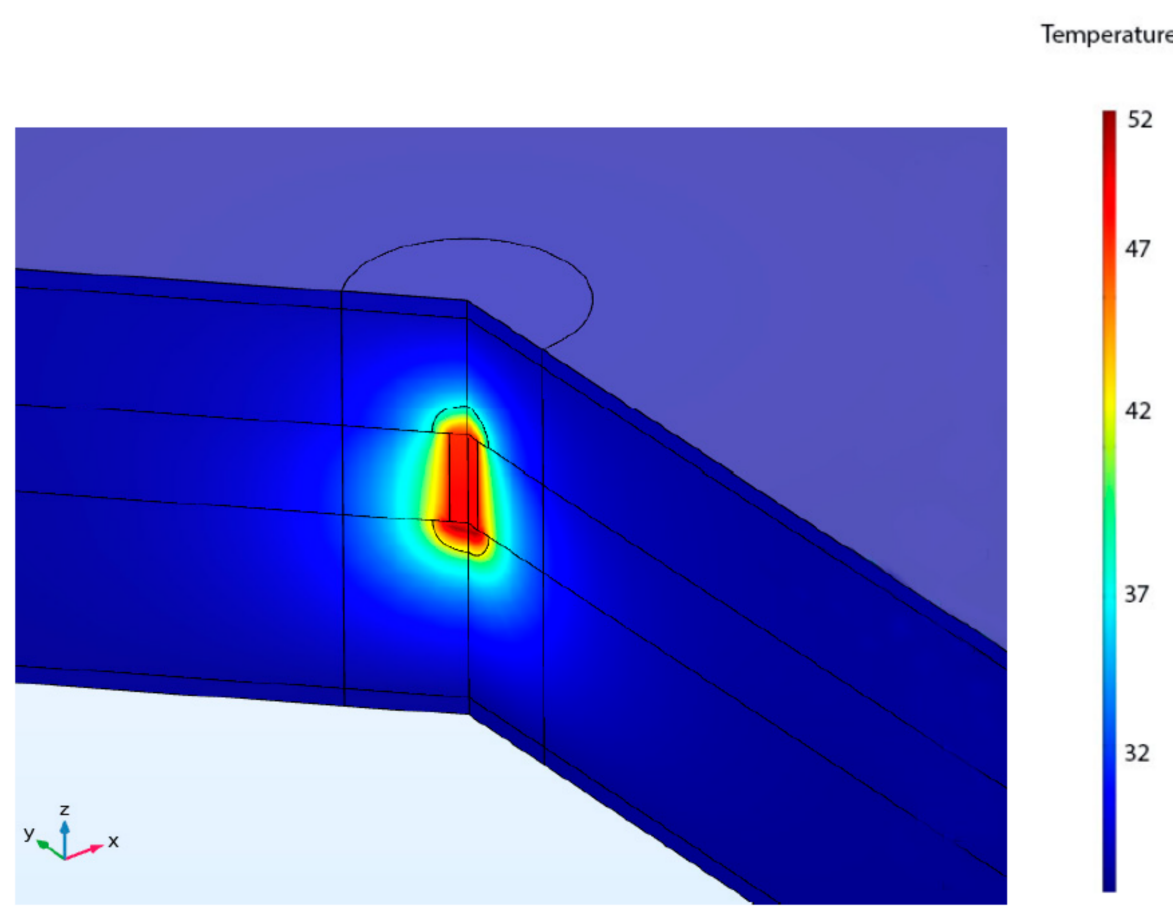

Figure 4. Internal short-circuit in $\mathrm{LiFePO}_{4}$ battery resulting in thermal runaway.

\section{Thermal Management Techniques}

Different cooling techniques have been studied in various research papers such as air cooling, liquid cooling, PCM, heat pipe cooling, etc. Each of these methods has its own merits and shortcomings. If the performance of all these methods is considered, the liquid cooling method shows the immense capability of controlling temperature. This section analyses the various advantages and disadvantages of these cooling techniques.

\subsection{Air Cooling}

The air-cooling method is classified into two types forced and natural. The heat dissipates through the convection type of heat transfer. The design of an air-cooling system is much simpler 
as Al-Hallaj [39] correlated the forced cookie method with the PCM and analyzed that at the low surrounding temperature it has the same impact as that of PCM. In [40] two types of cooling models were implemented i.e., the serial and the parallel structure. Most of the models implemented are based on these two types of structures. In pouch batteries, silica plates [41] are used for cooling as the small structure of the battery restricts any cooling channel. As derived from Newton's cooling law three types of heat transfer can take place: (i) rising the transfer of heat through convection (ii) expanding the surface area so that maximum heat will be dissipated (iii) maintaining a maximum temperature difference among the battery and the coolant.

$$
\varphi=h A \Delta T
$$

$h=$ Heat transfer coefficient $\left(\mathrm{W} / \mathrm{m}^{2} \mathrm{~K}\right) A=$ Heat transfer area $\left(\mathrm{mm}^{2}\right)$.

By increasing the airflow rate, the performance of air cooling improves and it reduces the internal temperature but the uniformity of temperature is not maintained [42,43]. From the above analysis, it is found that regardless of less complexity and low-cost batteries working under higher charging and discharging rates, this technique can control temperature up to some extent [39]. The other methods of cooling may be more efficient such as liquid cooling and PCM.

\subsection{Liquid Cooling}

In comparison to air cooling techniques, liquid cooling can be more efficient in reducing temperature [44]. Liquid cooling can produce much better results when applying for cooling large areas [5]. The performance of Li-ion batteries has been analyzed under different loads and the ability of different coolants while keeping the ambient conditions for battery constant in [45]. Various types of systems are built where a cooling plate is placed between two batteries such that the cooling could be applied indirectly [46,47]. In Ref. [48] a liquid-based cooling model that contains a small-sized channel has been used and it has been found that the temperature is very well maintained below $40{ }^{\circ} \mathrm{C}$. Another type of model having small-sized channel tubes has been considered in [49] where the battery cell thermal performance is analyzed under varying flow rates and rate of discharge. In [50] a fluid hydrofluoroether which is dielectric in nature has been tested for battery thermal management.

Another liquid-based cooling system [51] having a U-shaped channel has been investigated to study the battery performance and consequence of cooling on it. Also, the thermal performance for a battery stack has been studied with varying discharge rates, and heat flow between the battery cells is analyzed in [52]. Zhao [53] in his research improvised two constraints of the design i.e., reducing the flow path by expanding the flow channels and raising the contact area among the channel and the battery. Rao [54] also analyzed a short-channel plate for cooling and found that overall temperature first increased but with the increase in the flow rate of liquid the maximum temperature started decreasing. But with this technique, another problem arose which is the increased rate of coolant led to increased consumption of energy by the pump. Indirect cooling methods can be implemented by using coolants such as Gallium [55]. Hence, it can be concluded that the liquid cooling technique has a strong potential of providing an efficient cooling system.

\subsection{Refrigerant Cooling}

Refrigerant based cooling systems are a subclass of the liquid cooling system but components design and operations are complicated [56]. With the implementation of this method batteries' thermal performance has been improved significantly. This method simply extends the existing air-conditioning system used for maintaining the temperature inside the cabin by assimilating with the battery cooling unit. [57] Kruger et al. were the first to employ a refrigerant-based cooling system into a battery and investigated the utilization of energy under aggressive conditions and found that the refrigerants can maintain the temperature well below $40^{\circ} \mathrm{C}$. Another study [58] where the allocation of the refrigerant is recomposed for an air conditioning system but under increased loads resulted in increased demand for 
cooling and under varying loads the evaporators are forced to operate. So, from different studies of this cooling method, the results seem to be encouraging despite more power consumption by the system.

\subsection{Phase Change Material}

This method has a stronger control for the temperature. The distribution of temperature is more uniform throughout the battery and it can restrict the impact if a thermal runaway occurs to the adjacent batteries [59]. To reduce the thermal conductivity, some research considered to amend paraffin with other components such as the composition with nanoparticles [60], Carbon fiber [61], and copper mesh [62]. If the latent enthalpy is larger for the PCM then it is best suited for higher working temperature batteries. Although PCM exhibits uniformity in temperature distribution, if the coolant is at a distance it is unable to dissipate temperature from batteries.

\section{Modeling Aspects}

In this work, mainly two types of cooling techniques have been simulated using a practical $\mathrm{LiFePO}_{4}$ battery specification. Then the performance of these methods is evaluated based on how efficiently the temperature is controlled under different air and liquid flow rates.

\subsection{Air Cooling}

The airflow model for cooling Li-ion battery has been shown in Figure 5 . The battery module consists of three cells and in between the cells two coolant passages having dimensions of $3 \mathrm{~mm} \times 127 \mathrm{~mm} \times 229 \mathrm{~mm}$ are formed to diffuse the heat produced by the battery cells. Dimensions of the complete battery module are $229 \mathrm{~mm}$ in length, $127 \mathrm{~mm}$ in width and $141 \mathrm{~mm}$ thick. Here, the coolant passages have been designed considering the dimensions of the battery module. The direction of air flow [63] between the batteries has been shown in the model. Through the inlet, air enters and then flows vertically in between the battery cells thus absorbing the heat from cells and exits through the outlet passage. In both the passages only the inlet and outlet sides are open and other two sides are closed such that air will be directed to flow through the cells. Since, the heat capacity of air is very low the model has been designed in such a way that at a particular instant of time the maximum air will enter through the inlet passage. Radiator fans have been used to generate a large volume of air. It can be seen in Figure 5, that the air flows from the lower portion of the battery stack across its walls to the top the lower part of the battery first comes in contact with the cooler air, therefore, temperature at the lower edge reduces faster than the other parts of the battery. Therefore, the battery gets cooled with a nonuniform distribution of temperature from down to top.

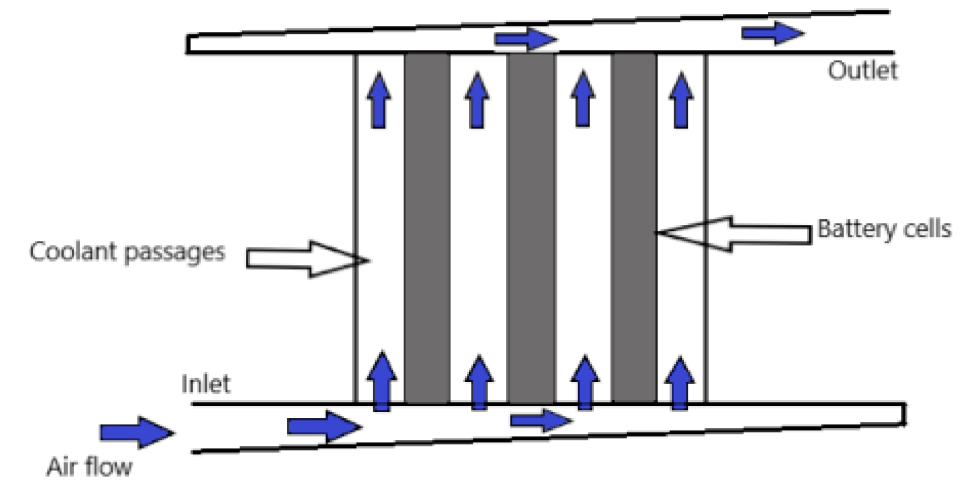

Figure 5. Schematic of the air-cooling system for Li-ion battery stack. 


\subsection{Liquid Cooling}

In indirect liquid cooling for varying flow rates of the coolant, the temperature variation of the battery pack has been analyzed. Coolant flows through channels of U-shape, which has been cut out from an Aluminum sheet of $100 \mathrm{~mm} \times 100 \mathrm{~mm} \times 5 \mathrm{~mm}$ dimensions. Since the geometry of battery cells has been considered here in a stacked shape, the Aluminum sheet is arranged in between the battery cells of $100 \mathrm{~mm} \times 100 \mathrm{~mm} \times 15 \mathrm{~mm}$ with a cooling fin and two flow connector channels both in the inlet and outlet side of cooling fins. The coolant used in this method is water [64]. The coolant is pumped into the channels by a coolant pump from the inlet side and released through the outlet side. It is then passed through a radiator fan assembly which cools down the water and again pumped into the fins by the pump. The varying charging/discharging rates produce heat in the battery pack as here a charge/discharge rate of $2 \mathrm{C}$ has been considered. Therefore, the heat produced is released from the battery stack through the coolant flowing through the channels.

Since, the coolant enters through the inlet side of the battery stack, the lower part of the stack closer to the inlet side starts cooling first. As, the coolant moves through the channels absorbing heat the other parts of the battery cools at a slower rate than the inlet side. Therefore, the channels are placed inside the battery stack in such a way that the contact between these channels and the battery surface is maximum as shown in Figure 6c. The temperature in this case also reduces non-uniformly from the left inlet side of the battery to the outlet side.

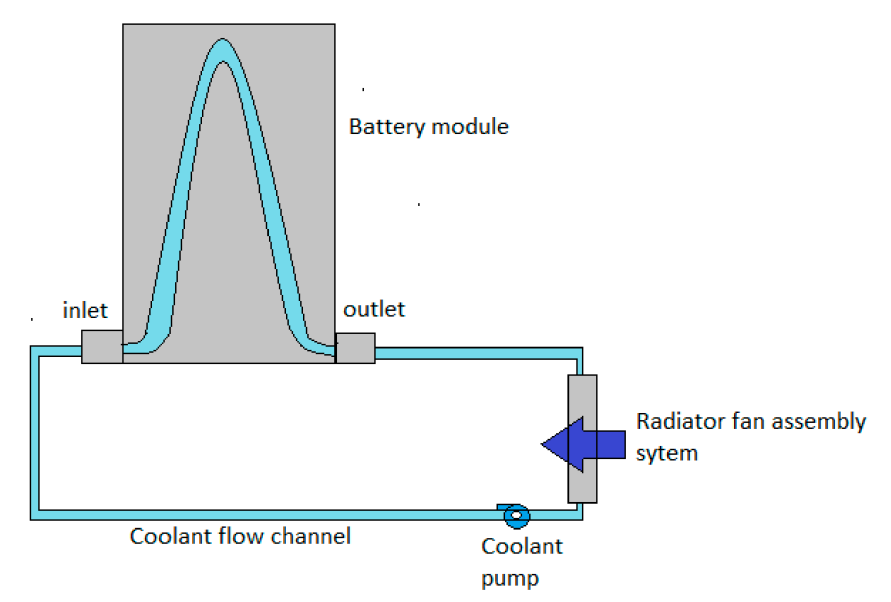

(a)

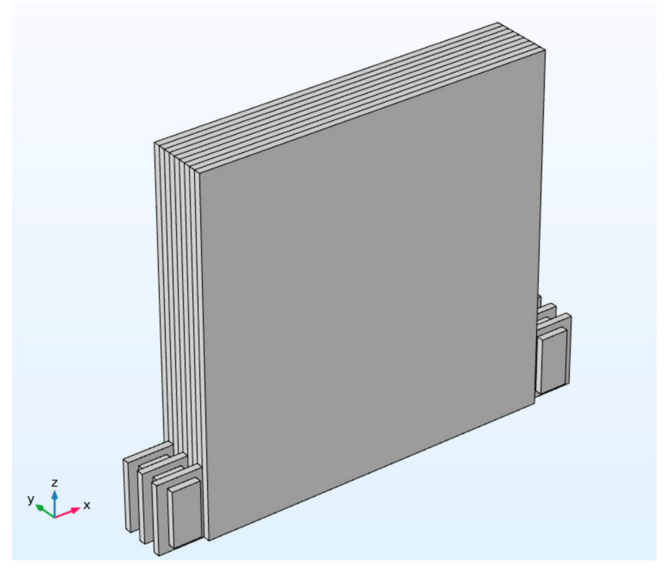

(b)

Figure 6. Cont. 


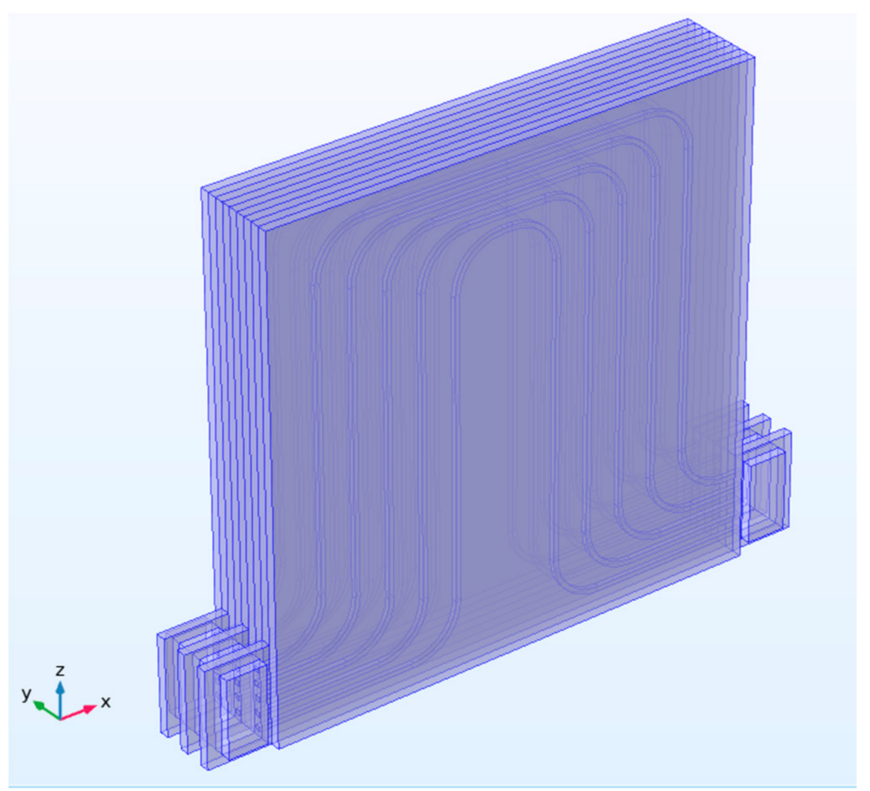

(c)

Figure 6. Liquid cooling setup: (a) Schematic of the liquid cooling arrangement for Li-ion battery stack; (b) The geometry of the battery model with inlet and outlet connector channel; (c) coolant flow channels inside battery stack.

\section{Results and Discussions}

\subsection{Air Cooling}

Since the coolant passages are responsible for the flow of air, an optimal design is built such that there would be a uniform distribution of airflow across the battery surface. Simulation of the battery has been performed under different flow rates where the velocity of the air is within the range of $0 \mathrm{~m} / \mathrm{s}$ to $10 \mathrm{~m} / \mathrm{s}$ and a constant $2 \mathrm{C}$ discharge rate is considered. The battery has been simulated for three cases when air flow rate of $V=0 \mathrm{~m} / \mathrm{s}$ i.e., the uncontrolled temperature and when $V=4 \mathrm{~m} / \mathrm{s}$ and $10 \mathrm{~m} / \mathrm{s}$. The maximum temperature of the battery without any cooling is found to be around $49.76{ }^{\circ} \mathrm{C}$ from Figures $3 \mathrm{~b}$ and $7 \mathrm{a}$ shows the battery module under this condition. After the liquid cooling system is applied, when the air flows at $V=4 \mathrm{~m} / \mathrm{s}$, the temperature of the battery drops from $49.76{ }^{\circ} \mathrm{C}$ to $43.36{ }^{\circ} \mathrm{C}$ which is represented in Figure $7 \mathrm{~b}$. As the velocity is increased to $V=10 \mathrm{~m} / \mathrm{s}$ maximum temperature drops to $34.52{ }^{\circ} \mathrm{C}$ which is shown in Figure 7c. Therefore, after the cooling system is applied to the battery the maximum temperature is reduced by $30.62 \%$ from $49.76{ }^{\circ} \mathrm{C}$ to $34.52{ }^{\circ} \mathrm{C}$ under different air flow rates. The simulations are performed for a single cycle.

Simulations show that as the flow rate of air increases the battery temperature decreases but with the rise in temperature, a larger volume of air is required to cool down the battery and the battery surface should be exposed to air uniformly such that maximum heat can be dissipated. As the forced cooling technique is used with increasing velocity of air, the power consumption of the system also increases, making it less efficient. 


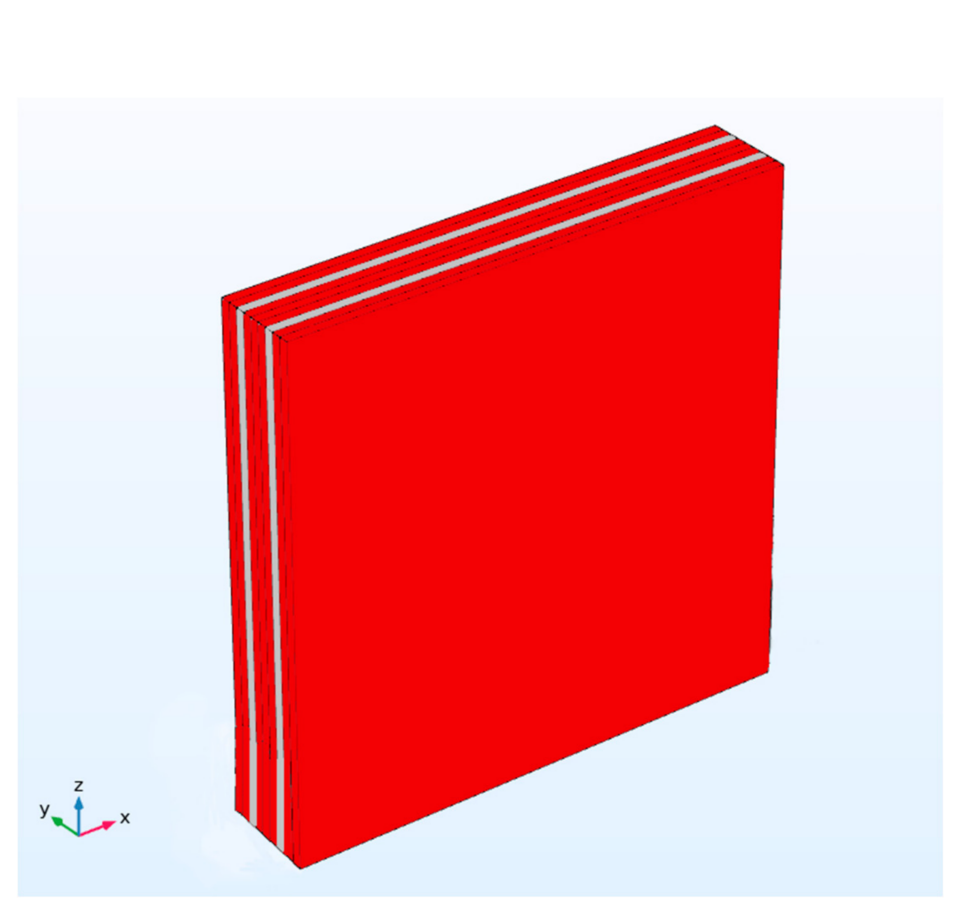

(a)

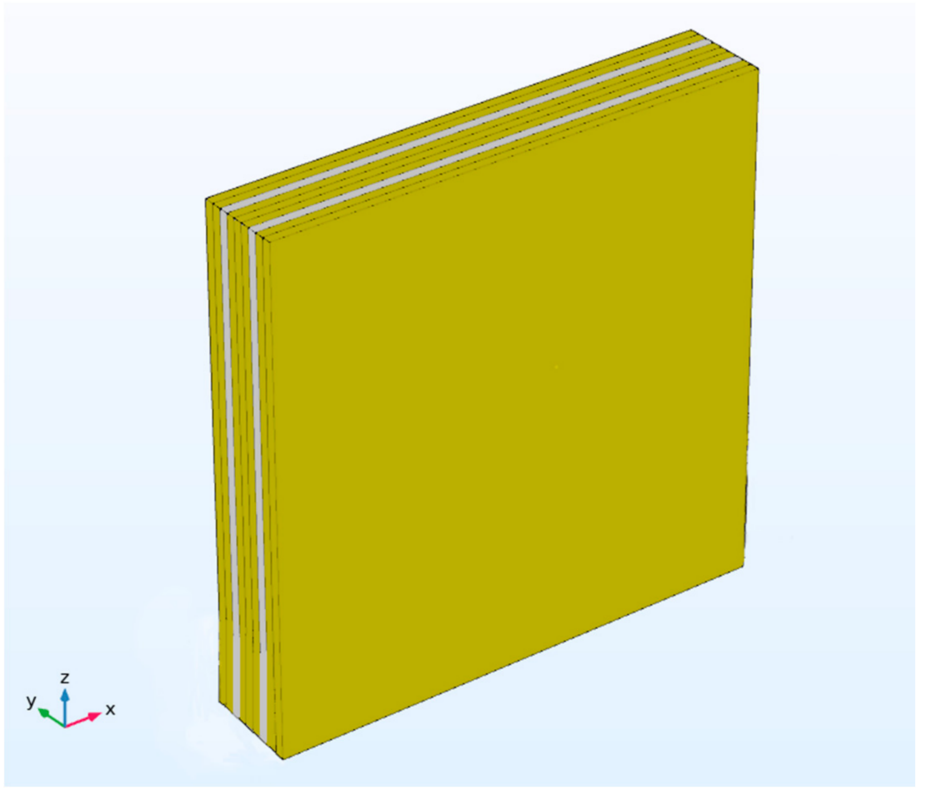

(b)

Figure 7. Cont.
Temperature $\left(^{\circ} \mathrm{C}\right)$

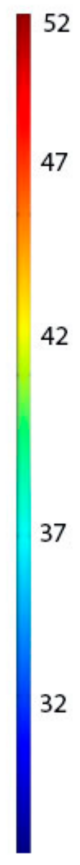

Temperature $\left.{ }^{\circ} \mathrm{C}\right)$

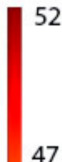

47

42

37

32
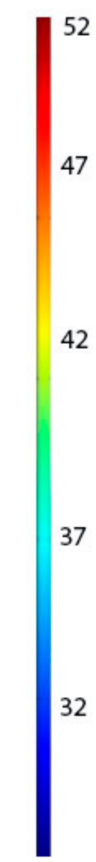


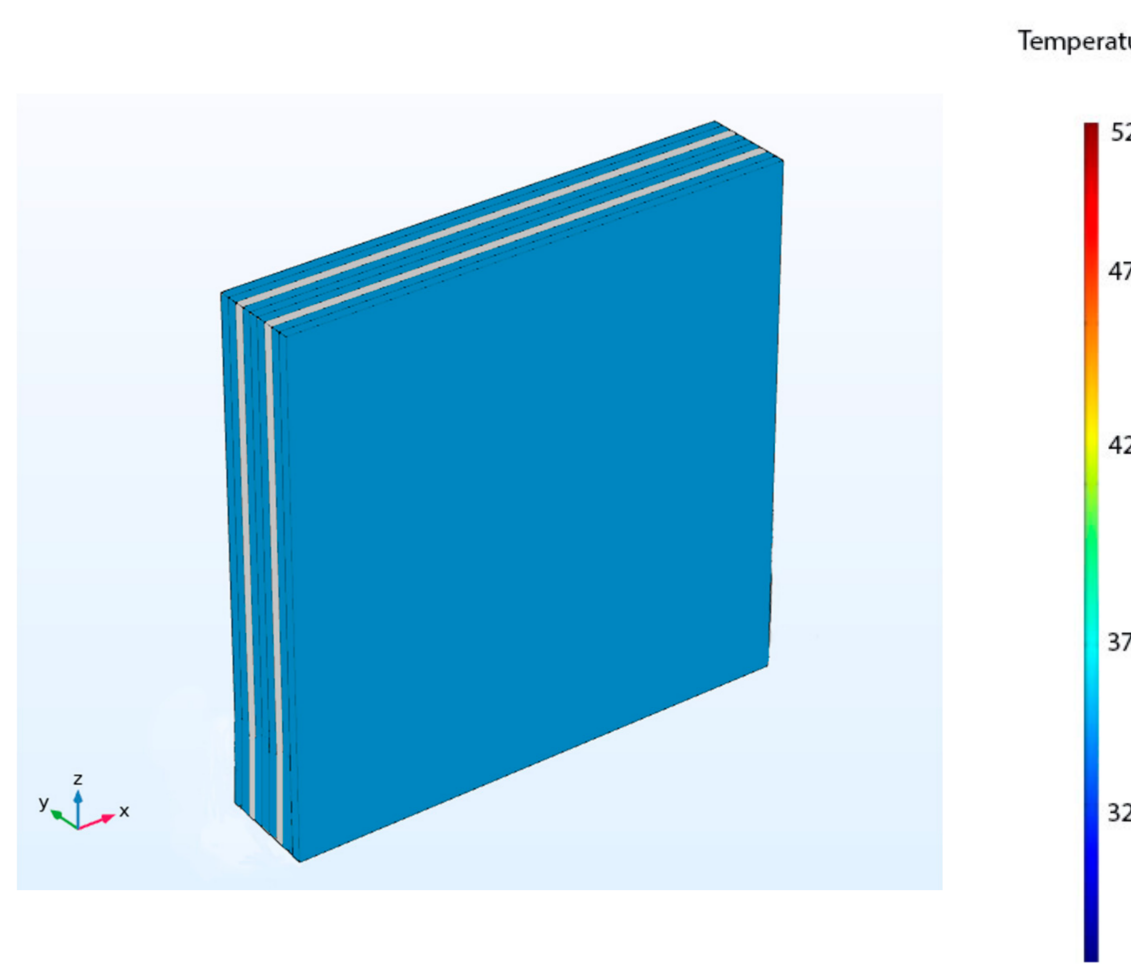

(c)

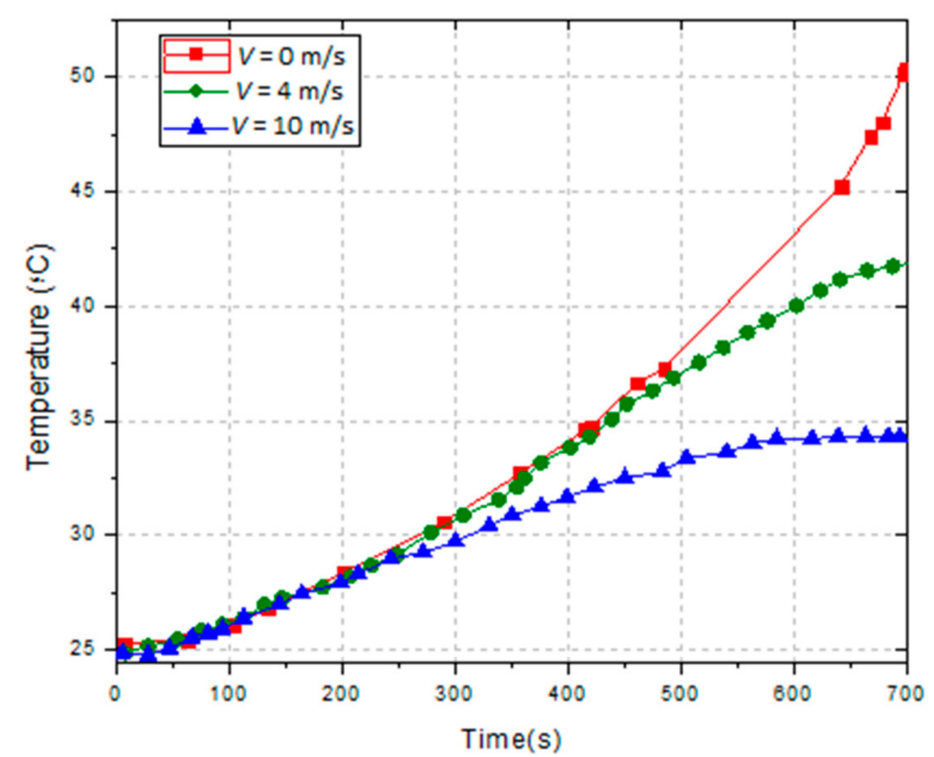

(d)

Figure 7. Comparison among the temperature variation inside the Li-ion battery stack under different airflow rates: (a) Temperature distribution inside the $\mathrm{LiFePO}_{4}$ battery stack without air flow cooling; (b) Temperature distribution inside the $\mathrm{LiFePO}_{4}$ battery stack at air flow of $V=4 \mathrm{~m} / \mathrm{s}$; (c) Temperature distribution inside the $\mathrm{LiFePO}_{4}$ battery stack at Air flow of $V=10 \mathrm{~m} / \mathrm{s}$; (d) Temperature curve under different air flow rate. 


\subsection{Liquid Cooling}

Since water has been considered here as the coolant, all the properties of the fluid are estimated by the inlet temperature. The thermal performance of the battery is mainly affected by the flow rate of the coolant. To observe the temperature variation of the battery simulations has been performed under different flow rates. The velocity of the fluid is within the range of $0 \mathrm{~m} / \mathrm{s}$ to $1 \mathrm{~m} / \mathrm{s}$ and a constant $2 \mathrm{C}$ discharge rate is considered. The battery has been simulated for four different values of coolant flow rate. The maximum temperature of the battery without any cooling is found to be around $49.76^{\circ} \mathrm{C}$ from Figure $3 \mathrm{~b}$ and represented in Figure $8 \mathrm{a}$ respectively. After the cooling system is applied, when the coolant flows at $V=0.001 \mathrm{~m} / \mathrm{s}$ the temperature of the battery drops from $49.76{ }^{\circ} \mathrm{C}$ to $45.36{ }^{\circ} \mathrm{C}$ which is shown below in Figure $8 \mathrm{~b}$. Similarly, at $V=0.005 \mathrm{~m} / \mathrm{s}$ maximum temperature is $34.46^{\circ} \mathrm{C}$ and at $V=0.01 \mathrm{~m} / \mathrm{s}$ maximum temperature is around $30.65^{\circ} \mathrm{C}$ and are shown in Figure $8 \mathrm{c}$, d respectively. Since the cooling system is applied to the battery, the maximum temperature is reduced from $49.76{ }^{\circ} \mathrm{C}$ to $30.65{ }^{\circ} \mathrm{C}$ under different coolant flow rates.

Simulation results demonstrate that the flow rate of the coolant determines the performance of the system as the flow rate increases more volume of coolant flows at a given time hence, more heat is dissipated from the battery and the temperature reduces.

Hence, from the above results, it is evident that the liquid cooling method is more efficient than air cooling method. The performance can further be improved if the contact area of the coolant with the battery surface increases. Therefore, an improvised immersion-based cooling system has been proposed here, where the battery module is immersed in the coolant such that maximum heat is dissipated within a short period.

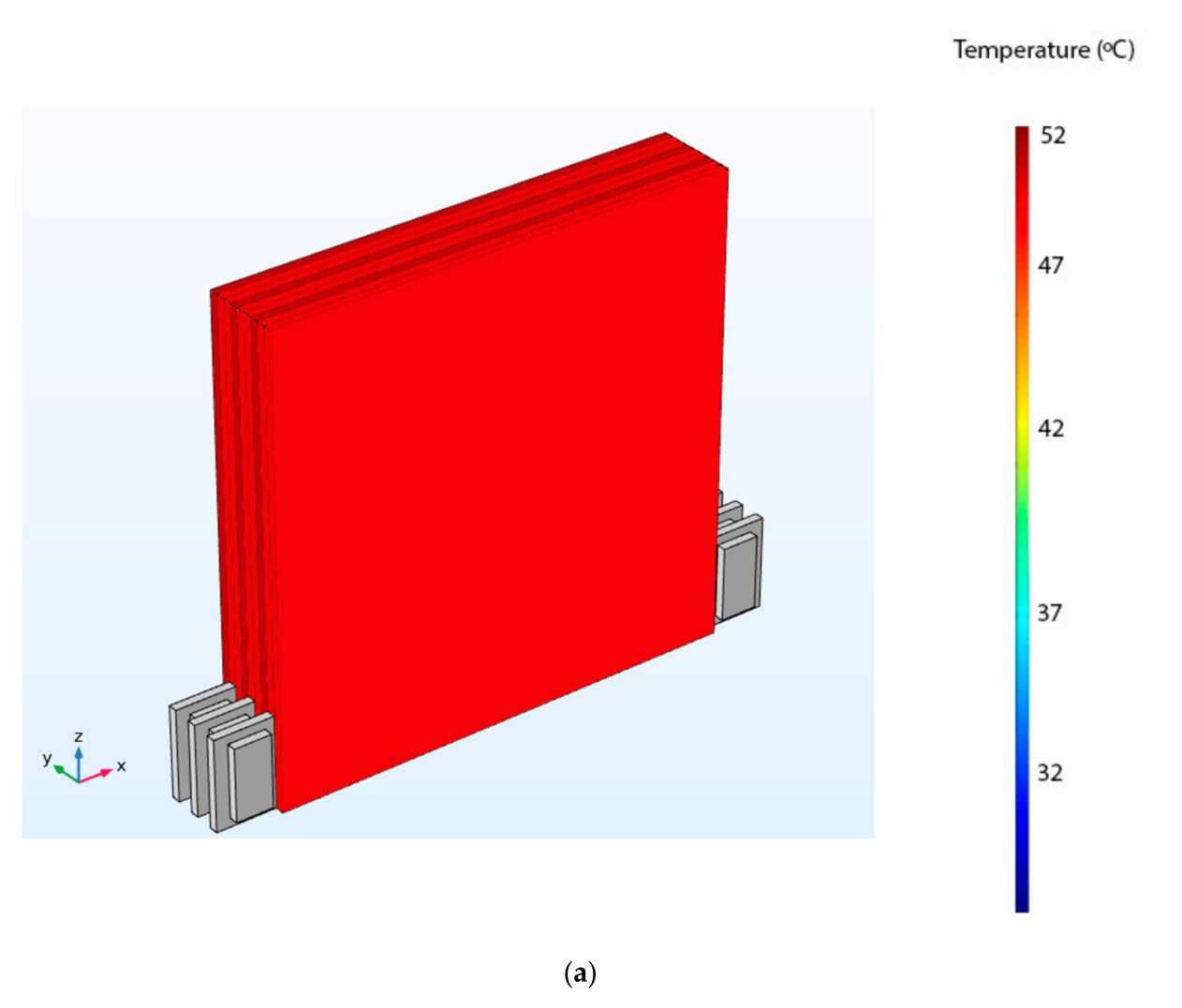

Figure 8. Cont. 


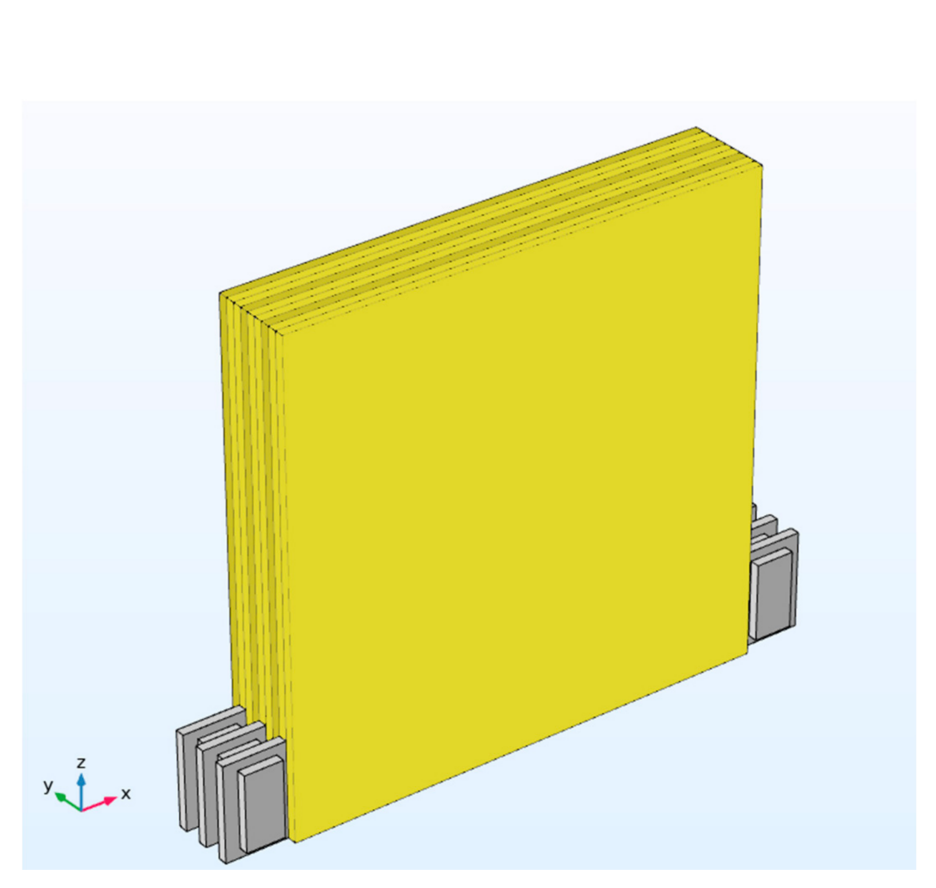

(b)

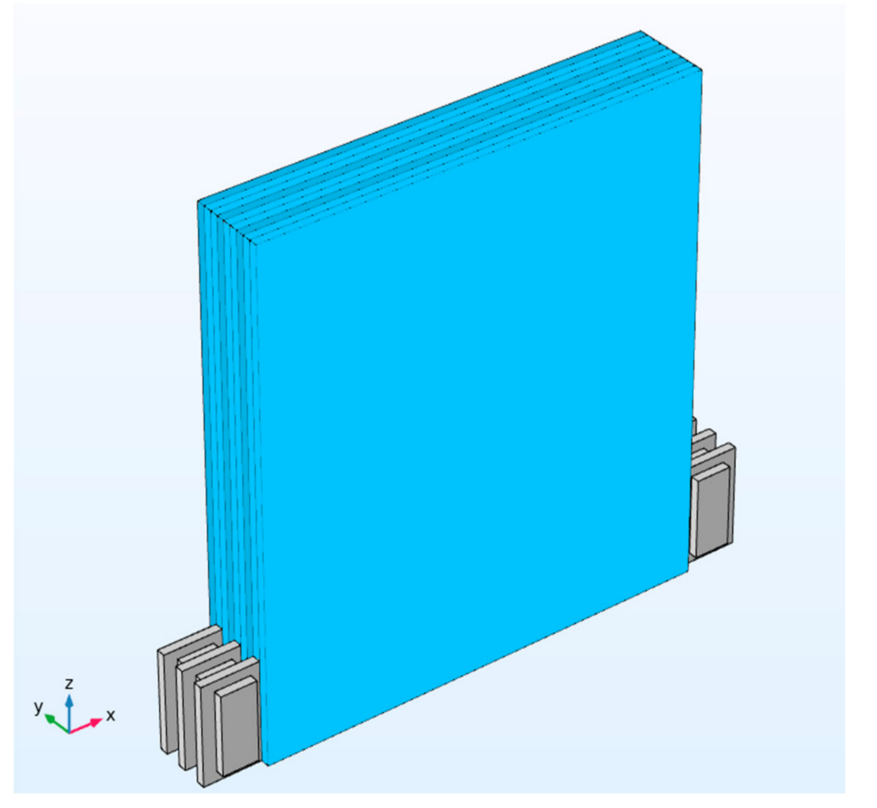

(c)

\section{Temperature $\left({ }^{\circ} \mathrm{C}\right)$}

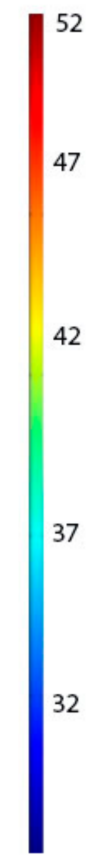

Temperature $\left.{ }^{\circ} \mathrm{C}\right)$

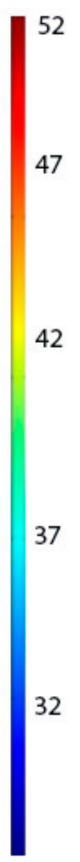

Figure 8. Cont. 


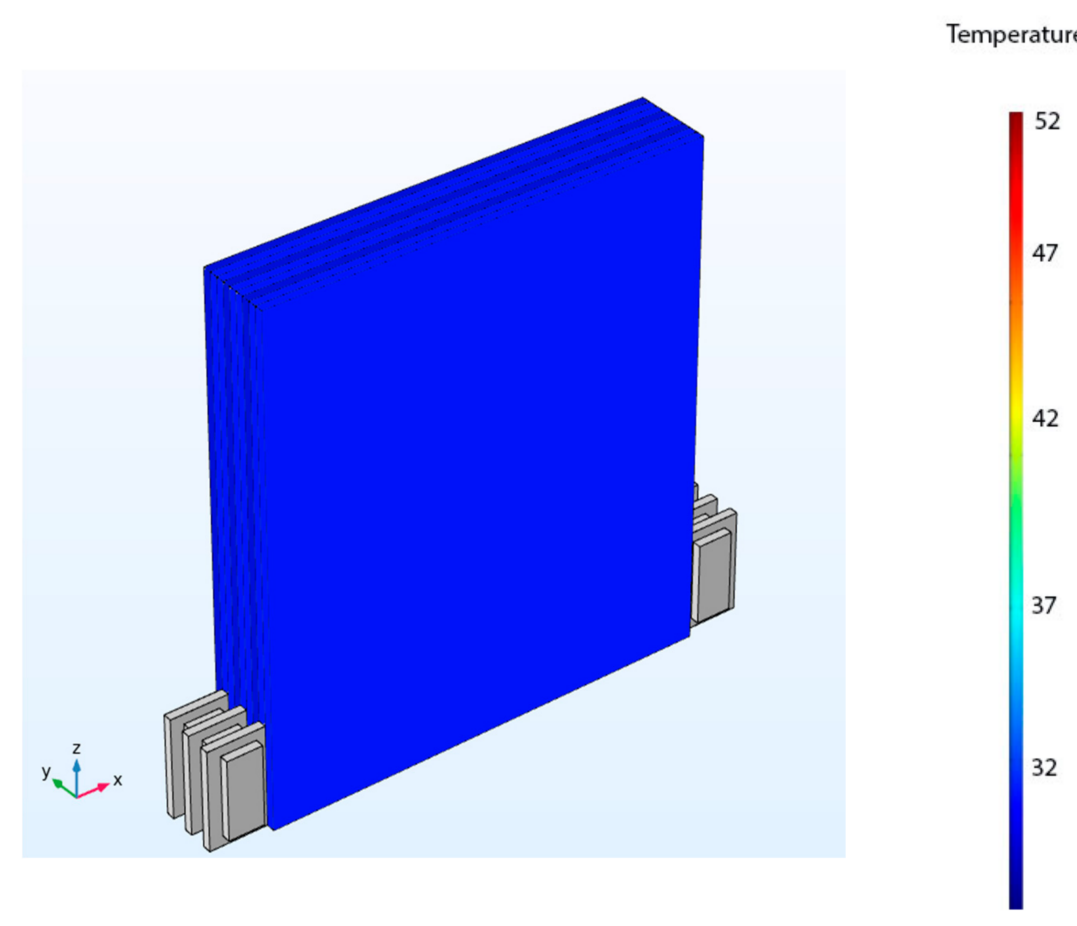

(d)

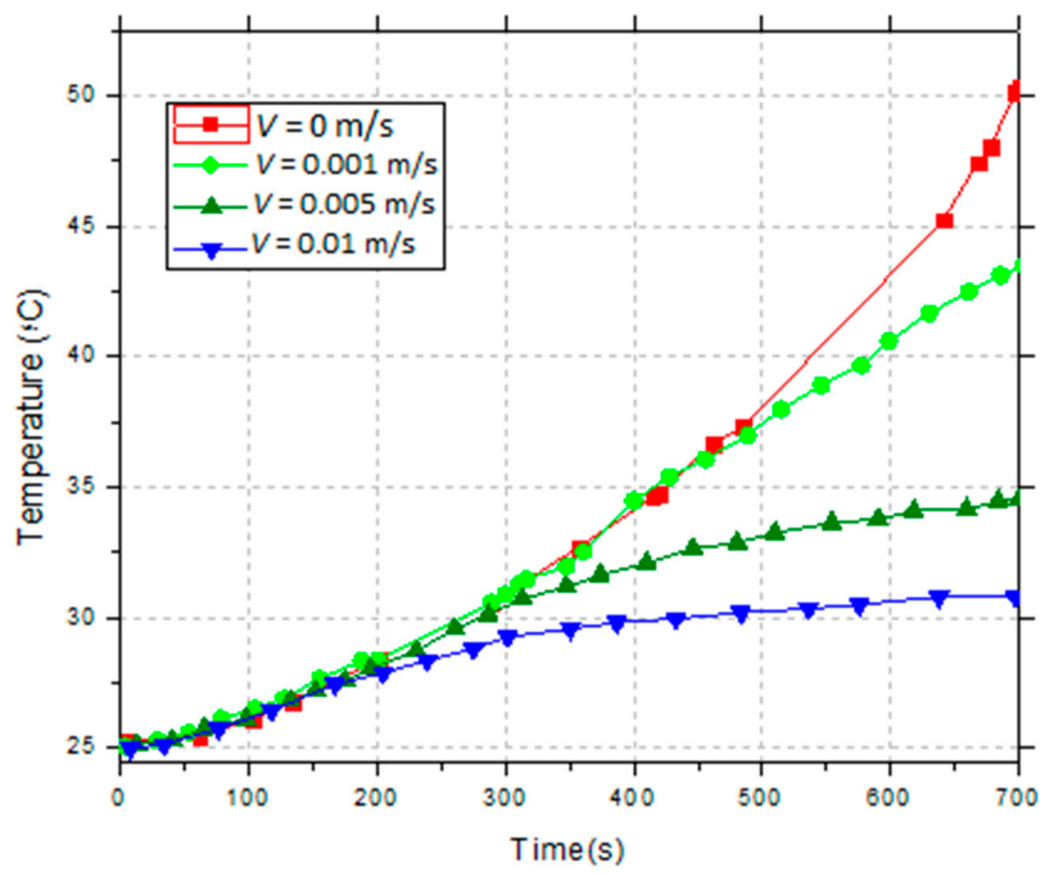

(e)

Figure 8. Performance of the liquid-cooling system under different coolant flow rates for a single cycle: (a) Temperature distribution inside the $\mathrm{LiFePO}_{4}$ battery stack without any coolant flow; (b) Temperature distribution inside the $\mathrm{LiFePO}_{4}$ battery stack under coolant flow rate of $V=0.001 \mathrm{~m} / \mathrm{s}$; (c) Temperature distribution inside the $\mathrm{LiFePO}_{4}$ battery stack under coolant flow rate of $V=0.005 \mathrm{~m} / \mathrm{s}$; (d) Temperature distribution inside the $\mathrm{LiFePO}_{4}$ battery stack under coolant flow rate of $V=0.01 \mathrm{~m} / \mathrm{s}$; (e) Temperature variations under the impact of different liquid flow rates. 


\section{Proposed Modified Liquid Cooling Technique- Immersion Based Liquid Cooling}

The proposed model is a type of indirect liquid cooling system. In the liquid cooling system, the coolant was flowing through the channels stacked between the battery cells whereas in this model instead of using channels, the battery module is directly immersed inside a dielectric coolant such that the discharge rate of heat from the battery will be faster and more efficient. Below is the figure of our proposed model.

Figure 9 shows the immersion-based liquid cooling system. In this model, a Li-ion battery module has been covered by a nonmetallic sheet of medium thickness to avoid direct contact of battery with the coolant as it may result in short-circuit. The module has been immersed in a container that contains a coolant having good thermal conductivity. Thermal sensors are attached outside the container as the coolant absorbs the heat from the battery through the nonmetallic sheet it measures the temperature of the coolant continuously and when the temperature increases up to a certain threshold degree the control valve- 1 gets initiated and opens. Then the coolant flows into the radiator fan assembly system where it is cooled by a radiator fan and when it is cooled after a certain time the control valve- 2 opens and then the coolant is pumped back to the container by a coolant pump.

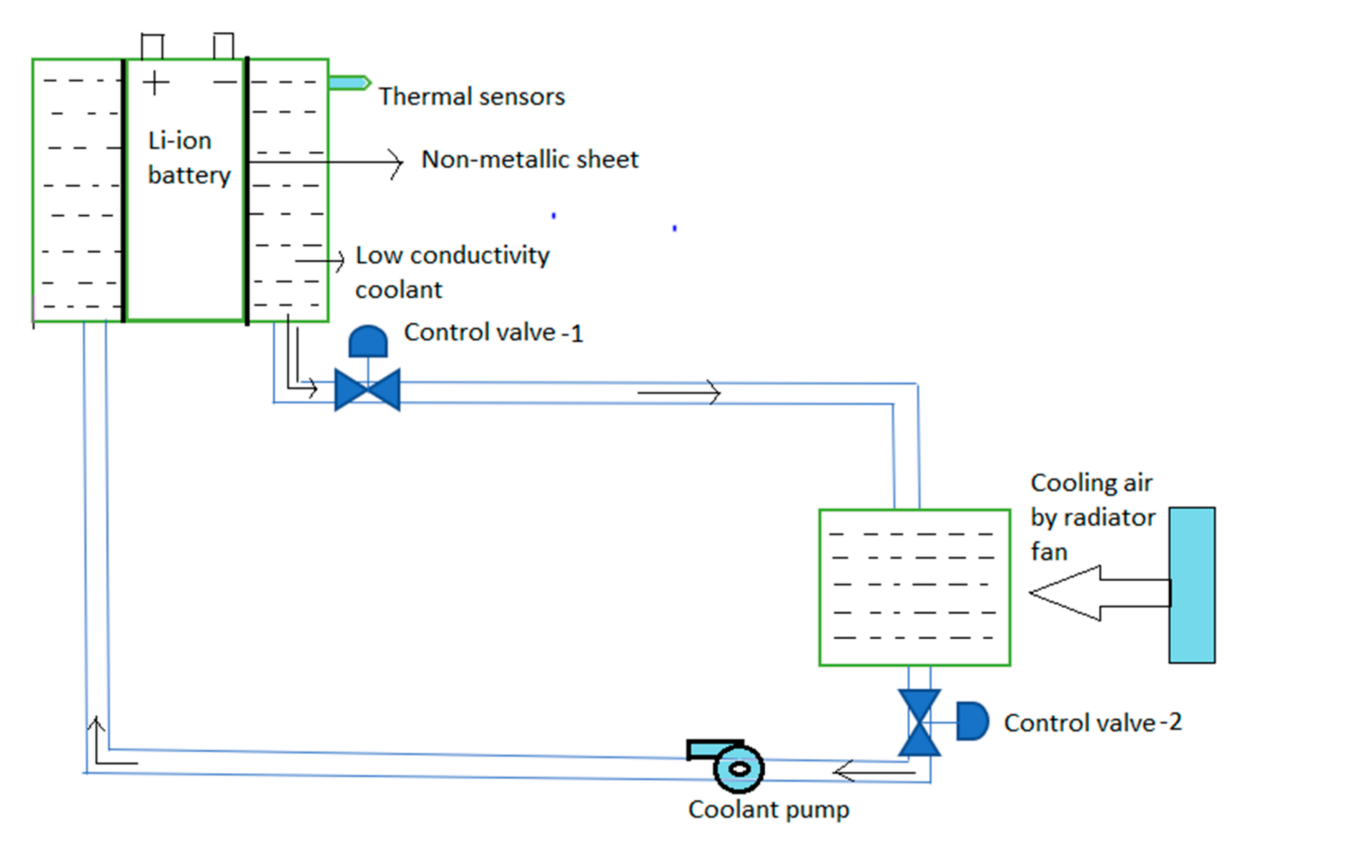

Figure 9. Proposed immersion based liquid cooling method for $\mathrm{LiFePO}_{4}$ battery.

The generated heat is directly dissipated through the liquid coolant by conduction method and then the heat is transferred to a heat exchanger device. The liquid is further sent to the battery stack by the pump and the cycle continues until the battery temperature comes under the safe limit. In comparison to other cooling methods dissipation of heat occurs much faster and uniformly with the same volumetric flow rate of coolant. The amount of heat to be dissipated from the battery depends mainly on the thermal conductivity of the coolant, its viscosity and density. Because of having a higher thermal conductivity, liquid coolants are able to discharge heat more effectively than air. The system has also lessened intricacy as it does not require any additional heat sink because of the liquid coolant being in proximity to the battery module. The coolant used here is dielectric in nature which provides a greater advantage over other types of coolants by providing a safeguard to the battery from thermal runaway, short-circuits or any hazards and have no safety issues as it is biodegradable [20] and are safer than other conductive coolant solutions which are rather toxic in nature. 


\section{Performance Analysis of Immersion Based Liquid Cooling Technique}

In order to analyze the performance of the proposed immersion based liquid cooling technique, the coolant which has been used in this work is the Ampcool Ac-100, designed by the 'Engineered Fluids' laboratory, ChemFoundry, 4548 Cantina Drive, Tyler, TX 75708, USA. It has a dielectric constant of 2.3 and much lesser value for the coefficient of thermal expansion ensuring that it won't expand under high temperature. Also, this coolant is biodegradable in nature thus eliminating any adverse environmental issues. Simulation studies done in this work are based on the experimental analysis of single-phase liquid immersion technology [20]. Figure 10 shows the cooling performance comparison among the air cooling, liquid cooling and immersion-based cooling methods. The air cooling and liquid cooling methods have been compared with immersion-based cooling system under the cases where the coolant is flowing at its maximum applied velocity. At the steady-state, it has been found that the $\mathrm{LiFePO}_{4}$ battery obtains a temperature of $27.43^{\circ} \mathrm{C}$ for immersion based liquid cooling whereas under indirect cooling the temperature comes down to $30.65^{\circ} \mathrm{C}$ and $34.52{ }^{\circ} \mathrm{C}$ for air cooling. Thus, the battery stack temperature difference in steady-state between the immersion based liquid cooling and the air cooling becomes $7.09^{\circ} \mathrm{C}$. The difference between the immersion based liquid cooling and indirect liquid cooling becomes $3.22{ }^{\circ} \mathrm{C}$ for the specified $\mathrm{LiFePO}_{4}$ battery.

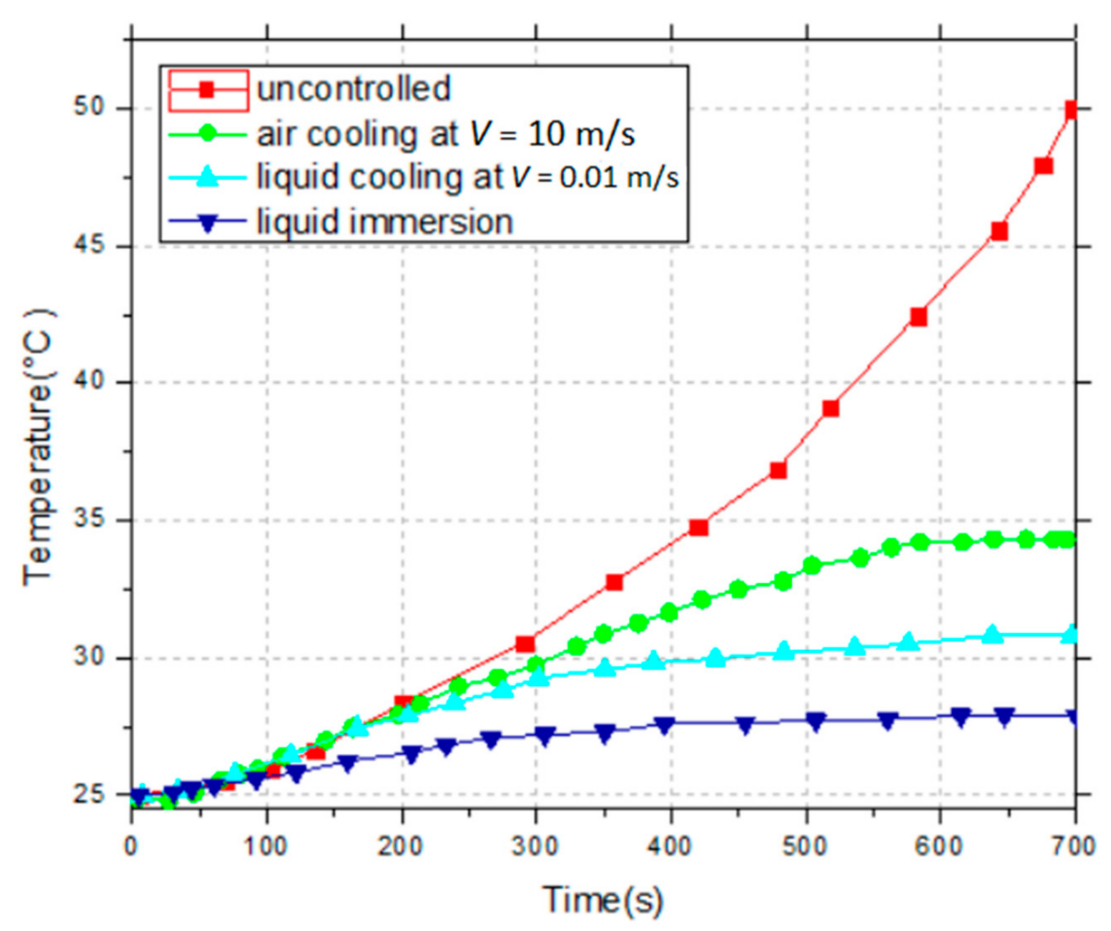

Figure 10. Temperature rise comparison between the uncontrolled and the liquid immersion cooling technique.

As in the case of the immersion based liquid cooling, the battery is directly immersed in the coolant, the heat dissipation capacity is increased and the efficiency of the cooling system gets improved. Therefore, the immersion based cooling system shows much better performance than both air and liquid cooling.

\section{Conclusions}

In this paper, an optimized thermal management scheme is proposed for a $\mathrm{kW}$ scale Li-ion battery stack. The cooling performances of two types of methods; air cooling and liquid cooling have been analyzed by implementing them on a $70 \mathrm{Ah}$, three cell stack $\mathrm{LiFePO}_{4}$ battery at high discharge 
rates. Both of these methods have shown promising results but the liquid cooling method possesses comparatively better performance. The modified cooling method i.e., immersion-based cooling model has been described. As the battery module is immersed in the coolant maximum heat is dissipated within a short period. This method will significantly improve the life cycle of the battery for long term usage. Results have demonstrated that the Li-ion battery pack having the maximum temperature of $49.76^{\circ} \mathrm{C}$ at $2 \mathrm{C}$ discharging rate has been reduced by $44.87 \%$, to $27.43^{\circ} \mathrm{C}$ under the impact of the immersion-based cooling system. The proposed thermal management scheme is a generalized one and thus can be very useful for the scalable Li-ion battery storage applications also.

Author Contributions: Conceptualization, A.B., A.G.; methodology, A.B., R.K.M.; software, R.K.M.; validation, A.B., R.K.M.; formal analysis, R.K.M.; investigation, A.B., R.K.M.; resources, A.B., R.K.M.; data curation, A.B., R.K.M.; writing-original draft preparation, A.B.; writing-review and editing, A.B.; A.G. visualization, A.B.; supervision, A.B., A.G.; project administration, A.G.; funding acquisition, A.G. All authors have read and agreed to the published version of the manuscript.

Funding: This research received no external funding.

Acknowledgments: The research work has been jointly done at the Department of Electrical and Electronics Engineering, BITS-Pilani Hyderabad Campus, India and at the University of Exeter, Penryn Campus, UK.

Conflicts of Interest: The authors declare no conflict of interest.

\section{References}

1. Lu, L.; Han, X.; Li, J.; Hua, J.; Ouyang, M. A review on the key issues for lithium-ion battery management in electric vehicles. J. Power Sources 2013, 226, 272-288. [CrossRef]

2. Yuksel, T.; Litster, S.; Viswanathan, V.; Michalek, J.J. Plug-in hybrid electric vehicle LiFePO4 battery life implications of thermal management, driving conditions, and regional climate. J. Power Sources 2017, 338, 49-64. [CrossRef]

3. Friesen, A.; Horsthemke, F.; Mönnighoff, X.; Brunklaus, G.; Krafft, R.; Börner, M.; Risthaus, T.; Winter, M.; Schappacher, F.M. Impact of cycling at low temperatures on the safety behaviour of 18,650-type Lithium ion cells: Combined study of mechanical and thermal abuse testing accompanied by post-mortem analysis. J. Power Sources 2016, 334, 1-11. [CrossRef]

4. Feng, X.; Sun, J.; Ouyang, M.; Wang, F.; He, X.; Lu, L.; Peng, H. Characterization of penetration induced thermal runaway propagation process within a large format lithium ion battery module. J. Power Sources 2015, 275, 261. [CrossRef]

5. Chen, D.; Jiang, J.; Kim, G.; Yang, C.; Pesaran, A. Comparison of different cooling methods for lithium ion battery cells. J. Power Sources 2016, 94, 846-854. [CrossRef]

6. Zolot, M.; Pesaran, A.A.; Mihalic, M. Thermal Evaluation of Toyota Prius Battery Pack; Technical Report, SAE Technical Paper; SAE International: Atlanta, GA, USA, 2002. [CrossRef]

7. Zolot, M.D.; Kelly, K.; Keyser, M.; Mihalic, M.; Pesaran, A.; Hieronymus, A. Thermal evaluation of the Honda Insight battery pack. In Proceedings of the Intersociety Energy Conversion Engineering Conference SAE, Savannah, Georgia, 29 July-2 August 2001; pp. 923-928.

8. Kelly, K.J.; Mihalic, M.; Zolot, M. Battery usage and thermal performance of the Toyota Prius and Honda Insight during chassis dynamometer testing. In Proceedings of the IEEE Battery Conference, Long Beach, CA, USA, 18 January 2002; pp. 247-252. [CrossRef]

9. Wang, Q.; Ping, P.; Zhao, X.; Chu, G.; Sun, J.; Chen, C. Thermal runaway caused fire and explosion of Lithium ion battery. J. Power Sources 2012, 208, 210-224. [CrossRef]

10. Pesaran, A.A.; Burch, S.; Keyser, M. An approach for designing thermal management systems for electric and hybrid vehicle battery packs. Veh. Therm. Manag. Syst. 1999, 4, 24-27.

11. Kim, G.; Pesaran, A.A. Battery thermal management design modelling. J. World Electr. Veh. 2007, 1, 126-133. [CrossRef]

12. Chacko, S.; Charmer, S. Lithium-ion pack thermal modelling and evaluation of indirect liquid cooling for electric vehicle battery thermal management. In Innovations in Fuel Economy and Sustainable Road Transport; Woodhead Publishing: Cambridge, UK, 2011; pp. 13-21. [CrossRef] 
13. Yeow, K.; Teng, H.; Thelliez, M.; Tan, E. Comparative study on thermal behaviour of lithium-ion battery systems with indirect air cooling and indirect liquid cooling. In Proceedings of the ASME/ISCIE 2012 International Symposium on Flexible Automation, St. Louis, MO, USA, 18-20 June 2012; pp. 585-591. [CrossRef]

14. Wu, M.S.; Liu, K.; Wang, Y.Y.; Wan, C.C. Heat dissipation design for lithium-ion batteries. J. Power Sources 2002, 109, 160-166. [CrossRef]

15. Peng, X.; Cui, X.; Liao, X.; Garg, A. A Thermal investigation and optimization of an air-cooled lithium ion battery pack. Energies 2020, 13, 2956. [CrossRef]

16. Rao, Z.; Wang, S. A review of power battery thermal energy management. Renew. Sustain. Energy Rev. 2011, 15, 4554-4571. [CrossRef]

17. Bandhauer, T.M.; Garimella, S.; Fuller, T.F. A critical review of thermal issues in lithium-ion batteries. J. Electrochem. Soc. 2011, 15, 1-25. [CrossRef]

18. Xia, B.; Liu, Y.; Huang, R.; Yang, Y.; Lai, Y.; Zheng, W.; Wang, H.; Wang, W.; Wang, M. Thermal analysis and improvements of the power battery pack with liquid cooling for electric vehicles. Energies 2019, 12, 3045. [CrossRef]

19. Hong, S.H.; Jang, D.S.; Park, S.; Yun, S.; Kim, Y. Thermal performance of direct two-phase refrigerant cooling for lithium-ion batteries in electric vehicles. Appl. Therm. Eng. 2020, 173, 115213. [CrossRef]

20. Sundin, D.W.; Sponholtz, S. Thermal Management of Li-Ion Batteries with Single-Phase Liquid Immersion Cooling. IEEE Open J. Veh. Technol. 2020, 1, 82-92. [CrossRef]

21. Bernardi, D.; Pawlikowski, E.; Newman, J. A General Energy Balance for Battery Systems. J. Electrochem. Soc. 1985, 5, 132. [CrossRef]

22. Mills, A.; Al-Hallaj, S. Simulation of passive thermal management system for lithium-ion battery packs. J. Power Sources 2005, 141, 307-315. [CrossRef]

23. Eddahech, A.; Briat, O.; Vinassa, J.-M. Thermal characterization of a high-power lithium-ion battery: Potentiometric and calorimetric measurement of entropy changes. J. Energy 2013, 61, 432-439. [CrossRef]

24. Shah, K.; Chalise, D.; Jain, A. Experimental and theoretical analysis of a method to predict thermal runaway in Li-ion cells. J. Power Sources 2016, 330, 167-174. [CrossRef]

25. Golubkov, A.W.; Fuchs, D.; Wagner, J.; Wiltsche, H.; Stangl, C.; Fauler, G.; Voitic, G.; Thaler, A.; Hacker, V. Thermal-runaway experiments on consumer Li-ion batteries with metal-oxide and olivine-type cathodes. RSC Adv. 2014, 4, 3633-3642. [CrossRef]

26. Drake, S.J.; Martin, M.; Wetz, D.A.; Ostanek, J.K.; Miller, S.P.; Heinzel, J.M.; Jain, A. Heat generation rate measurement in a Li-ion cell at large C-rates through temperature and heat flux measurements. J. Power Sources 2015, 285, 266-273. [CrossRef]

27. Jhu, C.Y.; Wang, Y.W.; Shu, C.M.; Chang, J.C.; Wu, H.C. Thermal explosion hazards on 18,650 lithium ion batteries with a VSP2 adiabatic calorimeter. J. Hazard. Mater. 2011, 192, 99-107. [CrossRef] [PubMed]

28. Jhu, C.Y.; Wang, Y.W.; Wen, C.Y.; Shu, C.M. Thermal runaway potential of LiCoO2 and Li(Ni1/3Co1/3Mn1/3)O2 batteries determined with adiabatic calorimetry methodology. Appl. Energy 2012, 100, 127-131. [CrossRef]

29. Chen, W.C.; Wang, Y.W.; Shu, C.M. Adiabatic calorimetry test of the reaction kinetics and self-heating model for $18650 \mathrm{Li}$-ion cells in various states of charge. J. Power Sources 2016, 318, 200-209. [CrossRef]

30. Cheng, X.; Li, T.; Ruan, X.; Wang, Z. Thermal Runaway Characteristics of a Large Format Lithium-Ion Battery Module. Energies 2019, 12, 3099. [CrossRef]

31. Jindal, P.; Bhattacharya, J. Review-Understanding the Thermal Runaway Behaviour of Li-Ion Batteries through Experimental Techniques. J. Electrochem. Soc. 2019, 166, 10. [CrossRef]

32. Feng, X.; Ouyang, M.; Liu, X.; Lu, L.; Xia, Y.; He, X. Thermal runaway mechanism of lithium ion battery for electric vehicles: A review. Energy Storage Mater. 2018, 10, 246-267. [CrossRef]

33. Ouyang, D.; Chen, M.; Liu, J.; Wei, R.; Weng, J.; Wang, J. Investigation of a commercial lithium-ion battery under overcharge/over-discharge failure conditions. RSC Adv. 2018, 8, 33414-33424. [CrossRef]

34. Jaguemont, J.; Boulon, L.; Dubé, Y. A Comprehensive Review on Lithium Ion Batteries used in Hybrid and Electric vehicle under Cold Temperature. Appl. Energy 2016, 164, 99-114. [CrossRef]

35. Jeevarajan, J. Safety of Commercial Lithium-Ion Cells and Batteries. In Lithium-Ion Batteries: Advances and Applications; Elsevier B.V.: Amsterdam, The Netherlands, 2014; pp. 384-407. [CrossRef]

36. Xia, L.; Zhu, L.; Haiyan, Z.; Ai, X. A positive-temperature-coefficient electrode with thermal protection mechanism for rechargeable lithium batteries. Chin. Sci. Bull. 2012, 57, 4205-4209. [CrossRef] 
37. Lopez, C.F.; Jeevarajan, J.A.; Mukherjee, P.P. Experimental Analysis of Thermal Runaway and Propagation in Lithium-Ion Battery Modules. J. Electrochem. Soc. 2015, 162, 9. [CrossRef]

38. Wilke, S.; Schweitzer, B.; Khateeb, S.; Al-Hallaj, S. Preventing thermal runaway propagation in lithium ion battery packs using a phase change composite material: An experimental study. J. Power Sources 2017, 340, 51-59. [CrossRef]

39. Sabbah, R.; Kizilel, R.; Selman, J.R.; Al-Hallaj, S. Active (air-cooled) vs. passive (phase change material) thermal management of high-power lithium-ion packs: Limitation of temperature rise and uniformity of temperature distribution. J. Power Sources 2008, 182, 630-638. [CrossRef]

40. Pesaran, A.A. Battery thermal models for hybrid vehicle simulations. J. Power Sources 2002, 110, 377-382. [CrossRef]

41. Li, X.; He, F.; Zhang, G.; Huang, Q.; Zhou, D. Experiment and simulation for pouch battery with silica cooling plates and copper mesh-based air-cooling thermal management system. Appl. Therm. Eng. 2019, 146, 866-880. [CrossRef]

42. Chen, S.C.; Wan, C.C.; Wang, Y.Y. Thermal analysis of lithium-ion batteries. J. Power Sources 2005, 140, 111-124. [CrossRef]

43. Mohammadian, S.K.; Zhang, Y. Thermal management optimization of an air-cooled Li-ion battery module using pin-fin heat sinks for hybrid electric vehicles. J. Power Sources 2015, 273, 431-439. [CrossRef]

44. Park, S.; Jung, D. Battery cell arrangement and heat transfer fluid effects on the parasitic power consumption and the cell temperature distribution in a hybrid electric vehicle. J. Power Sources 2013, 227, 191-198. [CrossRef]

45. Menale, C.; D'Annibale, F.; Mazzarotta, B.; Bubbico, R. Thermal management of lithium-ion batteries: An experimental investigation. Energy 2019, 182, 57-71. [CrossRef]

46. Yuan, H.; Wang, L.; Wang, L. Battery thermal management system with liquid cooling and heating in electric vehicles. J. Automot. Saf. Energy 2012, 3, 371-380. [CrossRef]

47. Patil, M.S.; Panchal, S.; Kim, N.; Lee, M.-Y. Cooling Performance Characteristics of 20 Ah Lithium-Ion Pouch Cell with Cold Plates along Both Surfaces. Energies 2018, 11, 2550. [CrossRef]

48. Zhao, J.; Rao, Z.; Li, Y. Thermal performance of mini-channel liquid cooled cylinder-based battery thermal management for cylindrical lithium-ion power battery. Energy Convers. Manag. 2015, 103, 157-165. [CrossRef]

49. Lan, C.; Xu, J.; Qiao, Y.; Ma, Y. Thermal management for high power lithium-ion battery by mini channel aluminium tubes. Appl. Therm. Eng. 2016, 101, 284-292. [CrossRef]

50. An, Z.; Jia, L.; Li, X.; Ding, Y. Experimental investigation on lithium-ion battery thermal management based on flow boiling in mini-channel. Appl. Therm. Eng. 2017, 117, 534-543. [CrossRef]

51. Deng, T.; Zhang, G.; Ran, Y. Study on thermal management of rectangular li-ion battery with serpentine-channel cold plate. Int. J. Heat Mass Transf. 2018, 125, 143-152. [CrossRef]

52. Zhao, C.; Cao, W.; Dong, T.; Jiang, F. Thermal behaviour study of discharging/charging cylindrical lithium-ion battery module cooled by channelled liquid flow. Int. J. Heat Mass Transf. 2018, 120, 751-762. [CrossRef]

53. Zhao, C.; Sousa, A.C.M.; Jiang, F. Minimization of thermal non-uniformity in lithium-ion battery pack cooled by channelled liquid flow. Int. J. Heat Mass Transf. 2019, 129, 660-670. [CrossRef]

54. Huo, Y.; Rao, Z.; Liu, X.; Zhao, J. Investigation of power battery thermal management by using mini-channel cold plate. Energy Convers. Manag. 2015, 89, 387-395. [CrossRef]

55. Yang, X.H.; Tan, S.C.; Liu, J. Thermal management of Li-ion battery with liquid metal. Energy Convers. Manag. 2016, 117, 577-585. [CrossRef]

56. Kim, J.; Oh, J.; Lee, H. Review on battery thermal management system for electric vehicles. Appl. Therm. Eng. 2019, 149, 192-212. [CrossRef]

57. Krüger, I.L.; Limperich, D. Energy Consumption of Battery Cooling in Hybrid Electric Vehicles. In Proceedings of the International Refrigeration and Air Conditioning Conference, West Lafayette, IN, USA, 16-19 July 2012.

58. Gillet, T.; Andres, E.; El-bakkali, A.; Lemort, V.; Rulliere, R.; Haberschill, P. Sleeping evaporator and refrigerant maldistribution: An experimental investigation in an automotive multi-evaporator air-conditioning and battery cooling system. Int. J. Refrig. 2018, 90, 119-131. [CrossRef]

59. Hémery, C.V.; Pra, F.; Robin, J.F.; Marty, P. Experimental performances of a battery thermal management system using phase change material. J. Power Sources 2014, 270, 349-358. [CrossRef]

60. Karimi, G.; Azizi, M.; Babapoor, A. Experimental study of a cylindrical lithium ion battery thermal management using phase change material composites. J. Energy Storage 2016, 8, 168-174. [CrossRef] 
61. Samimi, F.; Babapoor, A.; Azizi, M.; Karimi, G. Thermal management analysis of a Li-ion battery cell using phase change material loaded with carbon fibres. Energy 2016, 96, 355-371. [CrossRef]

62. Lv, Y.; Yang, X.; Li, X.; Zhang, G.; Wang, Z.; Yang, C. Experimental study on a novel battery thermal management technology based on low density polyethylene-enhanced composite phase change materials coupled with low fins. Appl. Energy 2016, 178, 376-382. [CrossRef]

63. Park, H. A design of air flow configuration for cooling lithium ion battery in hybrid electric vehicles. J. Power Sources 2013, 239, 30-36. [CrossRef]

64. Siruvuri, S.D.V.S.S.V.; Budarapu, P.R. Studies on thermal management of Lithium-ion battery pack using water as the cooling fluid. J. Energy Storage 2020, 29, 101377. [CrossRef]

Publisher's Note: MDPI stays neutral with regard to jurisdictional claims in published maps and institutional affiliations.

(C) 2020 by the authors. Licensee MDPI, Basel, Switzerland. This article is an open access article distributed under the terms and conditions of the Creative Commons Attribution (CC BY) license (http://creativecommons.org/licenses/by/4.0/). 